\title{
KINERJA PORTOFOLIO OPTIMAL PADA SAHAM SYARIAH ${ }^{\prime \prime}$
}

\author{
Mutmainah \\ Mahasiswa Program Studi Ekonomi Islam-Fakultas Ekonomi dan Bisnis-Universitas Airlangga \\ Email: mutmainah-12@feb.unair.ac.id \\ Imron Mawardi \\ Departemen Ekonomi Syariah-Fakultas Ekonomi dan Bisnis-Universitas Airlangga \\ Email: imron.mawardi@feb.unair.ac.id
}

\begin{abstract}
:
This study wants to describe whether an optimal portfolio which was formed in 20132015 it was good in 2016 compared to the performance of Jakarta Islamic Index and described as it is. The formation of the portfolio using single index model and the performance is measured by using the Sharpe index. This research is quantitative descriptive research. This research uses secondary data, carried out on the stock consistently at the Jakarta Islamic Index in January 2013-July 2016. Based on data, there were 18 shares actively and four stocks forming optimal portfolio composed of AKRA, TLKM, ICBP, and UNVR. Optimal portfolio performance in 2016 was 0,720 while the performance of the market was 0,676. With the results showed that it formed a good portfolio because the result was higher than the market. So investors or investment managers can make this portfolio as investment considerations.

Keywords: optimal portfolio, Single Index Model, the optimal portfolio performance, Sharpe index, Jakarta Islamic Index
\end{abstract}

\section{PENDAHULUAN}

\section{Latar Belakang}

Keberhasilan suatu perusahaan salah satunya ditentukan oleh kualitas keputusan keuangannya. Semakin bagus kondisi keuangan yang dimiliki perusahaan maka nilai perusahaan tersebut akan meningkat. Ketika perusahaan dalam kondisi bagus maka banyak investor yang akan menginvestasikan dananya pada perusahaan tersebut.

Investasi merupakan bentuk pengelolaan dana guna memberikan keuntungan dengan cara menempatkan dana pada alokasi yang diperkirakan akan memberikan tambahan keuntungan (Fahmi, 2006:2). Alfirdaus (2011:79) berpendapat bahwa mendapatkan keuntungan merupakan tujuan prioritas seorang investor.

Firman Allah dalam QS. An Nisaa' ayat 9 :

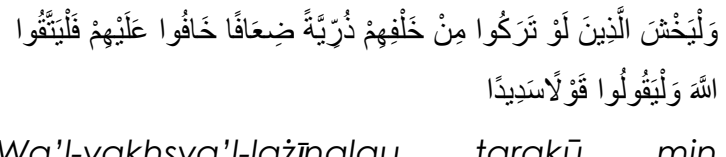
khalfihim żurriyyatan ḍi'āfan khāfū 'alaihim falyat-taqu'l-Lāha wa'l-yaqūlū qau lan sadīdan.

"Dan hendaklah takut kepada Allah orang-orang yang seandainya meninggalkan dibelakang mereka anakanak yang lemah, yang mereka khawatir terhadap(kesejahteraan) mereka. Oleh sebab itu hendaklah mereka bertaqwa kepada Allah dan hendaklah mereka mengucapkan perkataan yang benar".

1) Jurnal ini merupakan bagian dari skripsi dari Mutmainah. NIM 041211431015 yang diuji pada 31 Januari 2017 
Berdasarkan ayat diatas merupakan anjuran untuk berinvestasi. Namun dalam berinvestasi harus dilakukan sesuai dengan prinsip syariah berdasarkan firman Allah SWT dalam QS. Al-Baqarah ayat 275:

$$
\text { .... .... }
$$

“...wa ahalla'I-Lahu'I-bay'a wa harrama'rriba..."

"...dan Allah menghalalkan jual beli dan mengharamkan riba..."

Salah satu instrumen investasi yang sesuai Islam adalah investasi saham, dalam Fatwa Dewan Syariah Nasional Majelis Ulama Indonesia No. 20/DSNMUI/IX/2000 terdapat pedoman tentang Pelaksanaan Investasi untuk Reksadana Syariah, sehingga dengan ini menyimpulkan bahwa investasi saham dalam Islam diperbolehkan. Salah satu saham syariah adalah saham yang tercatat di Jakarta Islamic Index .

Saham Jll telah memenuhi syarat yang telah disebutkan Fatwa DSN-MUI No. 20/DSN-MUI/IX/2000, salah satunya usaha tidak mengandung unsur haram, riba, dan judi yang terus dievaluasi secara rutin enam bulan sekali untuk menjaga kosistensi kesyariahan, selain itu saham yang masuk di JII harus memiliki nilai kapitalisasi pasar yang bagus. Jakarta Islamic Index atau biasa disebut JII merupakan indeks saham di Bursa Efek Indonesia yang didasarkan atas prinsip syariah (Nafik, 2009:260). Jumlah saham yang berada di JII dipilih 30 saham yang terbaik setiap semesternya.
Penelitian ini fokus kepada saham disebabkan saham merupakan jenis investasi di Pasar Modal yang memiliki risiko yang tinggi. Ketika berinvestasi pada saham, pengembalian yang akan diterima akan maksimal jika dibanding dengan jenis investasi yang lain. Kenyataannya, seorang investor yang netral terhadap risiko cenderung mengambil posisi agresif maksimum. Jadi, wajar jika seorang investor cenderung memilih saham sebagai jenis investasinya. (Krugman dan Obstfeld 2000:509)

Mengingat saham adalah aset yang mempunyai risiko tinggi, maka diperlukan teknik yang baik supaya dapat meminimalisir risiko yaitu dengan cara membentuk portofolio. Seorang investor yang rasional, tentu akan memilih portofolio yang optimal, dan sebelum membentuk portofolio yang optimal, investor harus menentukan portofolio yang efisien terlebih dahulu. Portofolio efisien adalah portofolio yang memiliki nilai return paling tinggi dengan risiko tertentu atau portofolio yang memiki risiko paling rendah dengan return tertentu. Sedangkan portofolio optimal adalah portofolio yang dipilih oleh investor dari sekian banyak pilihan yang ada pada kumpulan portofolio yang efisien (Tandelilin, 2010:157).

Setelah portofolio optimal terbentuk maka perlunya dilakukan pengukuran kinerja portofolio. Kinerja portofolio adalah hasil yang telah dicapai oleh portofolio yang telah dibentuk 
investor dalam rangka meminimalkan risiko(Jogiyanto, 2010:635-636).

Tujuan dari penilaian kinerja portofolio investasi adalah untuk mengetahui apakah kinerja portofolio yang telah dibentuk sudah mampu memenuhi tujuan investasi yang ingin dicapai investor yaitu mampu memberikan tingkat return yang relatif lebih tinggi dibanding return portofolio lainnya, sesuai dengan tingkat risiko yang ditanggung investor (Herlianto, 2013: 163)

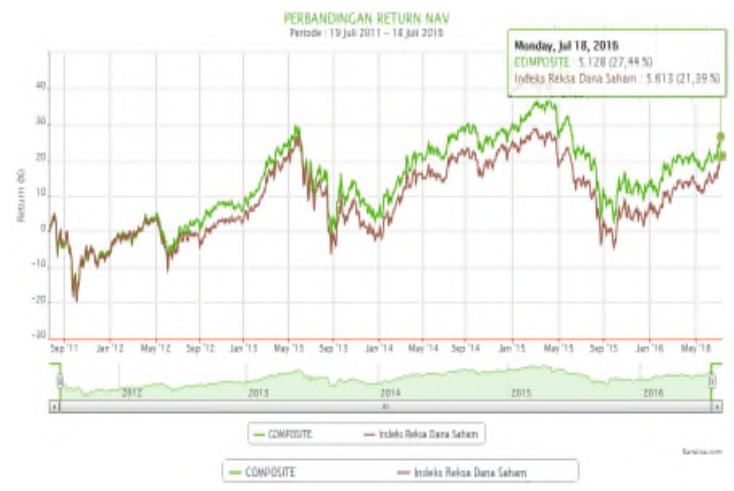

Sumber: www. Bereksa.com

Grafik 1

Perbandingan Kinerja Reksa Dana Saham dan IHSG

Pada reksa dana, terdapat fenomena pada periode Juli 2011-Juli 2016 bahwa kinerja pasar yang tercermin dari IHSG yaitu $27,14 \%$ sedangkan kinerja indeks reksa dana saham hanya $21,32 \%$, Jadi, lebih besar kinerja pasar dari pada kinerja reksa dana dengan selisih 5,82\%. Jadi, lebih besar kinerja pasar dari pada kinerja reksa dana dengan selisih 5,82\%. Seharusnya kinerja reksadana lebih baik dari pada kinerja pasar karena reksa dana merupakan saham yang sudah dipilih manajer investasi. Fenomena reksadana diatas sama seperti fenomena dalam penelitian yang dilakukan oleh Fitriaty dkk., (2012) berikut ini:

Tabel 1

Return Ekspektasi dan Kinerja

Portofolio Optimal Indeks JII 2010-2012

\begin{tabular}{|c|c|c|c|}
\hline No. & Tahun & E (R) & Kinerja (RVOL) \\
\hline 1 & 2010 & 0,3727 & 0,0490 \\
\hline 2 & 2011 & $-0,0393$ & 0,2467 \\
\hline 3 & 2012 & $-0,0498$ & 0,2995 \\
\hline
\end{tabular}

Sumber: Fitriaty dkk.2012. Analisis Kinerja Portofolio Optimal pada Saham-Saham Jakarta Islamic Index

Berdasarkan penelitian Fitriaty dkk.,

(2012) bahwa pada tahun 2010-2012 return ekspektasi $E(R)$ mengalami penurunan, tapi kinerja yang diukur dengan RVOL pada tahun 2010-2012 justru mengalami kenaikan.

Penelitian ini sesuai dengan pendapat Husnan (2003) dalam Herlianto (2013:163-164) bahwa tidaklah benar jika portofolio yang memberikan keuntungan yang lebih tinggi mesti lebih baik dari portofolio lainnya.

Pengukuran kinerja dalam penelitian ini menggunakan model Sharpe. Karena dalam indeks sharpe, risiko yang dianggap relavan adalah risiko total (penjumlahan risiko sistematis dan risiko tidak sistematis). Cara mengukurnya dengan membandingkan antara premi risiko portofolio (selisih rerata tingkat keuntungan portofolio dengan rerata suku bunga bebas risiko) dengan risiko portofolio yang dinyatakan dengan standar deviasi (risiko total) (Fitriaty dkk., 2012) 
Dalam penelitian ini, peneliti ingin mengetahui apakah portofolio yang terbentuk pada tahun 2013-2015 itu bagus atau tidak pada tahun 2016.Maka judul penelitian adalah "Kinerja Portofolio Optimal pada Saham Syariah".

\section{LANDASAN TEORI}

\section{Investasi}

Investasi adalah komitmen atas sejumlah dana atau sumber daya lainnya yang dilakukan pada saat ini dengan tujuan memperoleh keuntungan di masa datang (Tandelilin, 2010:2).

Kemudian dalam Islam, kegiatan bisnis dan investasi sangat dianjurkan. Walaupun begitu investasi dalam Islam tidak berarti setiap individu bebas melakukan tindakan untuk memperkaya diri atau menimbun kekayaan dengan cara tidak benar. Etika bisnis harus tetap dilandasi oleh normadan moralitas yang berlaku yang dalam ekonomi Islam bersumber dari Al-Qur'an dan Al-Hadits.

\section{Saham}

Saham merupakan salah satu bentuk penanaman modal pada suatu entitas (badan usaha) yang dilakukan dengan menyetorkan sejumlah dana tertentu dengan tujuan untuk menguasai sebagian hak pemilikan atas perusahaan. Pemegang saham atau investor mendapatkan hasil melalui pembagian deviden dan capital gain (Nafik, 2009:244).

Ketika berinvestasi untuk mengetahui pergerakan harga-harga saham maka dilihat dari pergerakan indeks yang disebut indeks harga saham yaitu 'rata-rata' dari sekumpulan harga saham dalam sebuah sektor tertentu. Rata-rata ditulis dalam tanda kutip karena perhitungannya tidak sekedar menghitung dengan rumus rat-rata pada umumnya.

\section{Jakarta Islamic Index}

Jakarta Islamic Index adalah indeks saham yang didasarkan atas prinsip syariah (Nafik, 2009:260). Saham yang dapat masuk ke dalam saham syariah harus memenuhi syarat yang telah disebutkan dalam Fatwa Dewan Syariah Nasional Majelis Ulama Indonesia No.20/DSN-MUI/IX/2000 tentang Pedoman Pelaksanaan Investasi untuk Reksadana Syariah.

Saham dalam JII terdiri dari 30 saham yang keanggotaannya akan terus ditinjau secara berkala berdasarkan kinerja transaksi di perdagangan bursa, rasio-rasio keuangannya, dan ketataannya pada prinsip-prinsip syariah.

\section{Portofolio}

Susilo (2009:150) menjelaskan bahwa Portofolio adalah kombinasi dari beberapa saham sebagai pilihan investasi. Tujuannya untuk meminimalkan risiko investasi dan mengoptimalkan keuntungan. Bahasa sederhananya adalah diversifikasi investasi.

Portofolio optimal merupakan portofolio yang dipilih oleh investor dari banyak pilihan yang ada pada kumpulan portofolio efisien. Portofolio yang dipilih investor tentunya adalah portofolio yang 
sesuai dengan preferensi investor terhadap return maupun risiko yang tersedia ditanggungnya. (Tandelilin, 2010:157).

\section{Model Indeks Tunggal}

Model Indeks Tunggal adalah sebuah teknik untuk mengukur return dan risiko sebuah saham atau portofolio. Model tersebut mengansumsikan bahwa pergerakan return saham hanya berhubungan dengan pergerakan pasar. Jika pasar bergerak naik, dalam arti permintaan terhadap saham meningkat, maka harga saham di pasar akan naik pula begitu sebaliknya (Zubir, 2011:97).

Model indeks tunggal akan mampu mengurangi jumlah variabel yang perlu ditaksir, karena model indeks tunggal mempunyai karakteristik: beta portofolio (Bp) yang merupakan rata-rata tertimbang dari beta saham-saham yang membentuk portofolio tersebut (Husnan ,1994:54) Beta saham dinyatakan dalam rumus:

$\beta i=\frac{\sigma_{i, m}}{\sigma^{2} m}$

Notasi:

Bi = Beta saham $\mathrm{i}$

$\sigma i, m=$ kovarian return saham i dengan return pasar

$\sigma 2 \mathrm{~m}=$ Variance return pasar

Portofolio Optimal Berdasarkan Model Indeks Tunggal

Model indeks tunggal adalah penyederhanaan dari model Markowitz. Menurut Bawasir dan Sitanggang (1994) dalam Soekarno (2007) bahwa metode indeks tunggal dapat digunakan dalam penentuan portofolio optimal dengan cara membandingkan excess return to beta (ERB) dengan cut-off-rate (Ci).

Nilai Excess return to Beta dirumuskan sebagai berikut (Jogiyanto, 2014:238-239):

$\mathrm{ERBi}=\frac{\mathbf{E}\left(\mathbf{R i}-\mathbf{R}_{\mathrm{f}}\right)}{\boldsymbol{\beta}_{\mathrm{i}}}$

Notasi :

ERBi =Excess Return to Beta saham ke $\mathrm{i}$ $\mathrm{Rf} \quad=$ Risk Free Rate of Return

$\mathrm{E}(\mathrm{Ri})=$ Return harapan dari investasi saham i

$\mathrm{Bi}=$ Beta saham ke $\mathrm{i}$

\section{Indeks Sharpe}

Indeks Sharpe dikembangkan oleh William Sharpe. kinerja portofolio dengan menggunakan metode ini diukur dengan cara membandingkan antara premi risiko portofolio (selisih rerata tingkat keuntungan portofolio dengan rerata suku bunga bebas risiko) dengan risiko portofolio yang dinyatakan dengan standar deviasi (risiko total).

Secara matematis indeks Sharpe diformulasikan sebagai berikut:

Spi $=\frac{\pi p i-R f}{s D p i}$

Notasi:

Spi = indeks Sharpe portofolio

Rpi = rerata imbal hasil portofolio $\mathrm{i}$

Rf =rerata atas bunga investasi bebas risiko

Sdpi = standar deviasi dari imbal hasil portofolio i

$\mathrm{Rpi}-\mathrm{Rf}=$ premi risiko portofolio

Oleh karena itu dalam penelitian ini menggunakan indeks sharpe. Karena dalam indeks sharpe, risiko yang 
dianggap relavan adalah risiko total (penjumlahan risiko sistematis dan risiko tidak sistematis).

\section{Kerangka Berfikir}

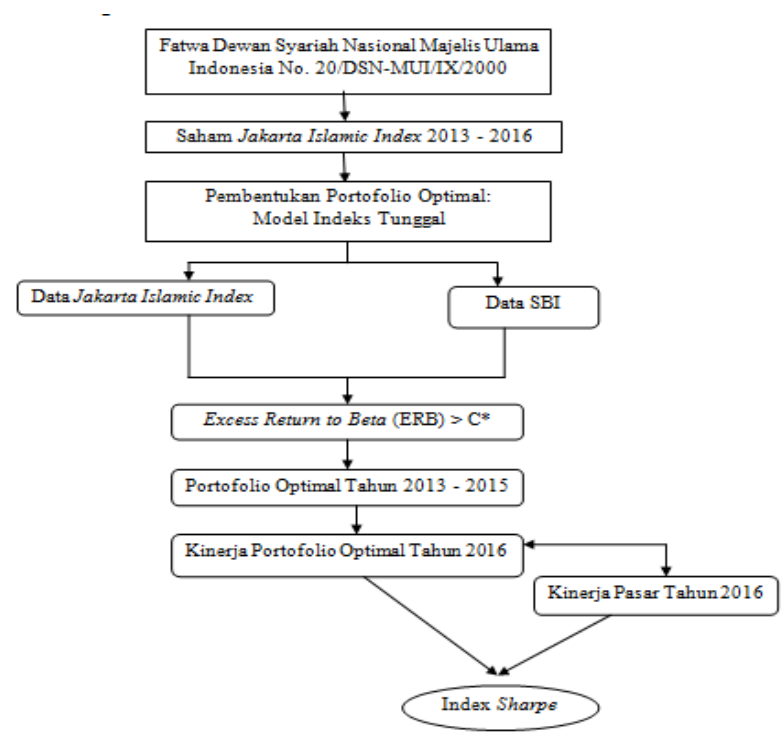

\section{METODE PENELITIAN}

Pendekatan penelitian yang digunakan dalam penulisan skripsi ini adalah pendekatan deskriptif kuantitatif.

Penelitian dekstiptif adalah metode penelitian yang dirancang untuk memperoleh informasi tentang status gejala saat penelitian dilakukan (Ary, 2007:447 dalam Prastowo, 2011 :202-203).

Teknik analisis data dalam penelitian kuantitatif menggunakan statistik, statistik deksriptif adalah statistik yang digunakan untuk menganalisis data dengan cara mendeksripsikan atau menggambarkan data yang telah terkumpul sebagaimana adanya tanpa bermaksud membuat kesimpulan yang berlaku secara umum atau generalisasi (Sugiyono, 2010:147)
Identifikasi variabel pada penelitian ini adalah portofolio optimal dan kinerja portofolio optimal.

Penentuan portofolio optimal dalam penelitian ini menggunakan metode indeks tunggal yaitu ERB lebih besar dari nilai $C^{*}\left(E R B>C^{*}\right)$. Sedangkan untuk kinerja portofolio optimal pengukurannya menggunakan model sharpe yang merupakan perhitungan yang mengukur tingkat total risiko.

Adapun definisi operasional dalam penelitian ini adalah:

a. Portofolio Optimal

Pembentukan portofolio optimal pada penelitian ini berdasarkan excess return to beta (ERB) masing-masing sekuritas. ERB merupakan kelebihan return sekuritas atas return asset bebas risiko (risk free rate) yang disebut dengan return premium per unit risiko yang diukur dengan beta.

Excess Return to Beta dapat dihitung dengan menggunakan rumus sebagai berikut:

Nilai Excess return to Beta dirumuskan sebagai berikut (Jogiyanto, 2014:238-239):

$\mathrm{ERBi}=\frac{\mathbb{E}\left(\mathrm{Ri}-\mathbb{R}_{\mathrm{f}}\right]}{\boldsymbol{\beta}_{\mathrm{i}}}$

Notasi :

ERBi = Excess Return to Beta saham ke $\mathrm{i}$

$\mathrm{Rf} \quad=$ Risk Free Rate of Return

$E($ Ri) = Return harapan dari investasi saham i

Bi = Beta saham ke $\mathrm{i}$

Untuk perhitungan ERB tersebut diperlukan perhitungan perhitungan sebelumnya sebagai berikut: 


\section{Realized return individual (Rit)}

Dengan rumus sebagai berikut (Jogiyanto, 2014:20):

Rit $=\frac{\mathbb{R}_{\mathrm{t}}-\mathrm{R}_{\mathrm{t}-1}+\mathrm{D}_{\mathrm{t}}}{\mathbb{R}_{\mathrm{t}-1}}$

Notasi :

Ri = return realisasi saham ke i pada periode $\dagger$

R† = Harga saham pada periode $\dagger$

$\mathrm{R}_{\mathrm{t}-1}=$ Harga saham pada periode sebelumya

Dt = Dividen saham yang dibayarkan pada periode $\dagger$

2. Return harapan (E(Ri))

Return harapan merupakan return yang diharapkan dari investasi yang akan dilakukan dengan program excell menggunakan rumus average atau rumus sebagai berikut (Jogiyanto, 2014:24-25):

$E(R i)=\frac{\sum_{i}^{n=1} R_{i t}}{n}$

Notasi :

$\mathrm{E}(\mathrm{Ri})=$ return harapan dari investasi saham i

Rit = return realisasi saham $\mathrm{i}$ pada periode $\dagger$

$\mathrm{n} \quad=$ Jumlah observasi

3. Return Market $\left(\mathrm{Rm}_{\mathrm{m}}\right)$

Digunakan untuk menghitung indeks return pasar. Dengan rumus sebagai berikut:

$$
\begin{aligned}
& R_{m}=\frac{j \mu_{t}-j u_{t-1}}{1 H S G_{t-1}} \\
& E\left(R_{m}\right)=\frac{\sum R_{m}}{n}
\end{aligned}
$$

Notasi:

$\mathrm{Rm} \quad=$ return pasar periode $\dagger$

$\mathrm{Jll}_{+} \quad=$ Jakarta Islamic Index periode $\dagger$
Jllt-1 =Jakarta Islamic Index periode sebelumnya

$E(R m)$ = return harapan pasar

$\mathrm{n}=$ waktu observasi standar deviasi

(०)

Digunakan untuk menghitung risiko dari return realisasi dari masing-masing saham. Dapat dihitung dengan menggunakan program excell dengan rUmUs STDEV atau dengan rumus sebagai berikut. (Jogiyanto, 2014:30):

$\sigma=\sqrt{\sum_{i=1}^{n} \frac{R_{i}-E\left(R_{i}\right)^{2}}{n}}$

Notasi:

$\sigma \quad=$ standar deviasi saham $\mathrm{i}$

$\mathrm{Ri}=$ return realisasi saham $\mathrm{i}$

$\mathrm{E}$ (Ri) = Return harapan saham $\mathrm{i}$

$\mathrm{n} \quad=$ jumlah return realisasi saham $\mathrm{i}$

$\sigma \mathrm{m}=\sqrt{\sum_{\mathrm{j}=1}^{\mathrm{n}} \frac{\mathbf{R}_{\mathbf{m r}}-\mathbf{E}\left(\mathbf{R}_{\mathrm{mz}}\right)^{\mathbf{2}}}{\mathbf{n}}}$

Notasi :

$\sigma \quad=$ standar deviasi pasar

$\mathrm{R}_{\mathrm{mt}} \quad=$ return pasar ke $\dagger$

$E\left(R_{m}\right)=$ return harapan pasar

$\mathrm{n} \quad=$ jumlah return realisasi saham $\mathrm{i}$

5. Variance $\left(\sigma^{2} \mathrm{i}\right)$

Digunakan untuk mengukur risiko return harapan dari masing - masing saham, merupakan kuadrat dari standar deviasi. Dapat dihitung dengan menggunakan program excel menggunakan rumus VAR atau menggunakan rumus (Jogiyanto, 2014:33):

$$
\begin{aligned}
& \sigma^{2}=\sum_{i=1}^{n} \frac{R_{i}-\mathbb{E}\left(R_{i}\right)^{n}}{n} \\
& \sigma^{2}=\sum_{i=1}^{n} \frac{\mathbf{R}_{m}-\mathbf{E}\left(\mathbb{R}_{m}\right)^{2}}{n}
\end{aligned}
$$

6. Variance $\left(\sigma_{e i}\right)$ 
Varian dari residual error saham i yang juga merupakan risiko unik atau tidak sistematik. Variance dihitung dengan rumus (Tandelilin, 2010:169):

$\sigma$ ei (i) $=\sigma^{2} i-\left(\sigma^{2} m \cdot(\text { ai })^{2}\right)$

Notasi :

$\Sigma_{\text {ei }}$ (i) $=$ Variance ei saham $\mathrm{i}$

$\sigma^{2} \mathrm{i} \quad=$ Variance saham $\mathrm{i}$

$\sigma^{2} \mathrm{~m} \quad=$ Variance pasar

$\alpha \mathrm{i} \quad=$ alpha saham $\mathrm{i}$

7. Beta ( $\beta i)$

Model indeks tunggal akan mampu mengurangi jumlah variabel yang perlu ditaksir, karena model indeks tunggal mempunyai karakteristik beta (Husnan, 1994:54). Beta dapat dihitung dengan program excell menggunakan rumus slope atau dinyatakan dalam rumus:

$\beta \mathrm{i}=\frac{\sigma_{i \mathrm{~m}}}{\sigma^{2} \mathrm{~m}}$

Notasi:

$$
\begin{aligned}
\beta \mathrm{i} & =\text { Beta saham } \mathrm{i} \\
\sigma \mathrm{i}, \mathrm{m} & =\text { kovarian return saham i dengan } \\
& \text { return pasar } \\
\sigma^{2} \mathrm{~m} & =\text { Variance return pasar }
\end{aligned}
$$

8. Alpha (a)

Alpha merupakan intercept return realisasi saham i dengan return realisasi pasar yang dapat membandingkan perhitungan return realisasi saham i dengan return pasar dalam periode waktu tertentu. Alpha dihitung dengan program excell menggunakan rumus intercept atau menggunakan rumus: (Tandelilin , 2010:132):

$\alpha i=R i-\beta i$

Notasi:

$$
\begin{aligned}
\alpha \mathrm{i} & =\text { alpha saham ke } \mathrm{i} \\
\beta \mathrm{i} & =\text { Beta saham ke } \mathrm{i} \\
\mathrm{Rm}_{\mathrm{m}} & =\text { Return pasar }
\end{aligned}
$$

9. Nilai Ai dan $\mathrm{Bi}$

Nilai Ai dihitung untuk mendapatkan nilai Aj dan Bidihitung untuk mendapatkan nilai Bj di mana keduanya diperlukan untuk menghitung $\mathrm{Ci}$. Penentuan nilai $\mathrm{Ai}$ dan Bi untuk masing - masing saham ke i sebagai berikut:

$$
\begin{aligned}
\mathrm{Ai} & =\frac{\left[\mathbb{E}\left(\mathrm{R}_{\mathrm{i}}\right)-\mathrm{R}_{\mathrm{f}}\right\rfloor \cdot \beta_{\mathrm{i}}}{\sigma_{\mathrm{ei}}} \\
\mathrm{Bi} & =\frac{\beta_{\mathrm{i}}{ }^{2}}{\sigma_{\mathrm{ei}}}
\end{aligned}
$$

Notasi:

$$
\begin{array}{ll}
\mathrm{E}(\mathrm{Ri}) & =\text { expected return saham } \mathrm{i} \\
\mathrm{Rf} & =\text { risk free rate of return } \\
\beta \mathrm{i} & =\text { beta saham } \mathrm{i} \\
\sigma \mathrm{ei} & =\text { variance saham (unique risk) }
\end{array}
$$

10. Titik pembatas (Ci)

Merupakan nilai $C$ untuk saham ke I yang dihitung dari akumulasi nilai-nilai $\mathrm{A} 1$ sampai $A i$ dan nilai-nilai $B 1$ sampai dengan Bi. Nilai Ci merupakan hasil bagi varian pasar dan return premium terhadap variance error saham. Dihitung dengan menggunakan rumus:

$C i=\frac{\sigma^{2} m \sum_{j=1}^{i} A_{i}}{1+\sigma^{2} m \sum_{j=1}^{i} B_{i}}$

Notasi :

$$
\sigma^{2} \mathrm{~m} \quad=\text { variance realized return pasar }
$$

11. Cut - off-Point ( $\left.C^{*}\right)$

Merupakan nilai Ci terbesar dari sederetan nilai Ci saham.

b. Penilaian Kinerja Portofolio pengukuran kinerja portofolio dalam penelitian ini diukur dengan cara 
membandingkan antara premi risiko portofolio (selisih rerata tingkat keuntungan portofolio dengan rerata suku bunga bebas risiko) dengan risiko portofolio yang dinyatakan dengan standar deviasi (risiko total) (Halim 2015:51) Secara matematis indeks sharpe diformulasikan sebagai berikut:

Spi $\quad=\frac{k p i-R i f}{S D p i}$

Notasi:

Spi = indeks Sharpe portofolio

Rpi = rerata imbal hasil portofolio $\mathrm{i}$

Rf = rerata atas bunga investasi bebas risiko

SDpi = standar deviasi dari imbal hasil portofolio i

$\mathrm{Rpi}-\mathrm{Rf}=$ premi risiko portofolio

Teknik pengambilan sampel dalam penelitian ini menggunakan Nonprobability Sampling dan teknik sampelnya adalah sampling purposive. Nonprobability Sampling yaitu tidak memberi peluang atau kesempatan sama bagi setiap unsur atau anggota populasi untuk dipilih menjadi sampel. Kemudian Sampling Porposive yaitu sampel yang ditetapkan secara sengaja oleh peneliti (Wirartha, 2006:240). Kriteria tersebut adalah:

1. Saham perusahaan yang terdaftar dan aktif diperdagangkan di Bursa Efek Indonesia periode Januari 2013-Juli 2016 dengan alasan bahwa saham-saham tersebut adalah saham-saham yang telah stabil di JII (tidak masuk dan keluar daftar saham emiten perhitungan Jakarta Islamic Index).
2. Data 30 saham yang terdaftar di Jakarta Islamic Index periode pengamatan Januari 2013-Juli 2016, data Jakarta Islamic Index ini di gunakan sebagai pasar untuk membentuk portofolio optimal tahun 2013-2015 dan mengukur kinerja pasar tahun 2016.

3. Data SBI dari periode Januari 2013 - Juli 2016.

Teknik Analisis dalam penelitian ini adalah a. Metode indeks tunggal untuk pembentukan portofolio tahun 2013-2015

Adapun langkah-langkah yang akan dilakukan adalah sebagai berikut: (1) Memilih saham yang akan diikutkan dalam portofolio (2) Menghitung realized return, expected return, standar deviasi dan variance dari masing-masing saham individual, pasar, dan SBI (3) Menghitung beta, alpha, dan varian error masingmasing saham individual (4) Menghitung nilai excess return to beta (ERB) masingmasing saham (5) Menghitung nilai $\mathrm{Ci}$ (6) Mencari nilai $C^{*}$.

b. Metode Sharpe untuk mengukur kinerja portofolio optimal tahun 2016.

Adapun langkah-langkahnya adalah sebagai berikut:

(1.) Menghitung return portofolio dan return pasar pada tahun 2016 (2) Menghitung standar deviasi portofolio dan standar deviasi pasar tahun 2016 (3) Menghitung kinerja portofolio dan kinerja pasar tahun 2016 dengan menggunakan indeks sharpe.

\section{A. Deskripsi Hasil Penelitian \\ 1. Pembentukan Portofolio Optimal}


Penentuan portofolio optimal dengan metode ini melalui beberapa tahapan:

a. Realized return, expected return, standar deviasi dan variance, variance error dari saham individual, pasar, dan SBI

Tabel 2

Return Ekspektasi, Standar Deviasi, Variance Saham Individual

\begin{tabular}{|c|c|c|c|}
\hline KODE & $\mathbf{E}(\mathbf{R i})$ & $\mathbf{\sigma i}$ & $\mathbf{\sigma}^{\mathbf{2}} \mathbf{i}$ \\
\hline AALI & 0.002 & 0.093 & 0.009 \\
\hline ADRO & -0.027 & 0.107 & 0.011 \\
\hline AKRA & 0.019 & 0.066 & 0.004 \\
\hline ASII & -0.002 & 0.049 & 0.002 \\
\hline ASRI & -0.012 & 0.120 & 0.014 \\
\hline BSDE & 0.012 & 0.074 & 0.005 \\
\hline ICBP & 0.017 & 0.064 & 0.004 \\
\hline INDF & -0.001 & 0.061 & 0.004 \\
\hline INTP & 0.003 & 0.052 & 0.003 \\
\hline ITMG & -0.043 & 0.099 & 0.010 \\
\hline KLBF & 0.008 & 0.056 & 0.003 \\
\hline LPKR & 0.008 & 0.083 & 0.007 \\
\hline LSIP & -0.007 & 0.113 & 0.013 \\
\hline PGAS & -0.010 & 0.078 & 0.006 \\
\hline SMGR & -0.007 & 0.064 & 0.004 \\
\hline TLKM & 0.017 & 0.046 & 0.002 \\
\hline UNTR & -0.003 & 0.064 & 0.004 \\
\hline UNVR & 0.018 & 0.065 & 0.004 \\
\hline TOTAL & $\mathbf{0 . 0 0 0}$ & $\mathbf{0 . 0 2 2}$ & $\mathbf{1 . 3 8}$ \\
\hline
\end{tabular}

Sumber: diolah oleh penulis

Dari 18 sampel saham, terdapat 9 saham yang memiliki return ekspektasi positif dan 9 saham yang memiliki return ekspektasi negatif. Return ekspektasi E(Ri) tertinggi dimiliki oleh AKRA dengan nilai 0,019 , sedangkan Return ekspektasi $E(R i)$ terendah dimiliki oleh ITMG dengan nilai 0,043 .

Kemudian untuk risiko return diukur dengan standar deviasi ( $\sigma i)$ dan variance $\left(\sigma^{2 i}\right)$. Dari semua saham standar deviasi dan variance bernilai positif. Standar deviasi yang paling tinggi adalah ASRI dengan nilai 0,120 dan standar deviasi terendah adalah TLKM dengan nilai 0,046.

Sedangkan variance tertinggi adalah ASRI dengan nilai 0,14 dan variance terendah adalah ASIl dan TLKM dengan nilai 0,002. Semakin tinggi nilai standar deviasi dan variance maka semakin tinggi pula nilai risikonya begitu pulal sebaliknya.

Tabel 3

Return Ekspektasi, Standar Deviasi, Variance Pasar dan SBI

\begin{tabular}{l|c|l|}
\hline & Jakarta Islamic Index (Rm) & SBI(Rf) \\
\hline $\mathrm{E}(\mathrm{Ri})$ & 0.000 & 0.007 \\
\hline $\boldsymbol{\sigma} \mathbf{i}$ & 0.035 & 0.075 \\
\hline $\boldsymbol{\sigma}^{2} \mathrm{i}$ & 0.001 & 0.006 \\
\hline
\end{tabular}

Sumber: diolah oleh penulis

Ekspektasi, Standar deviasi, variance pasar masing-masing memiliki nilai 0,000, 0,035 dan 0,001 . Return pasar bernilai positif, dapat dikatakan bahwa melakukan investasi pada saham yang terdaftar di Jakarta Islamic Index periode 2013-2015 memberikan keuntungan bagi investor. Sedangkan return ekspektasi, standar deviasi,variance SBI masingmasing memiliki nilai $0,007,0,075$ dan 0,006 .

b. Beta, alpha dan variance error masingmasing saham individual

Tabel 4

Beta, Alpha, dan Variance Error

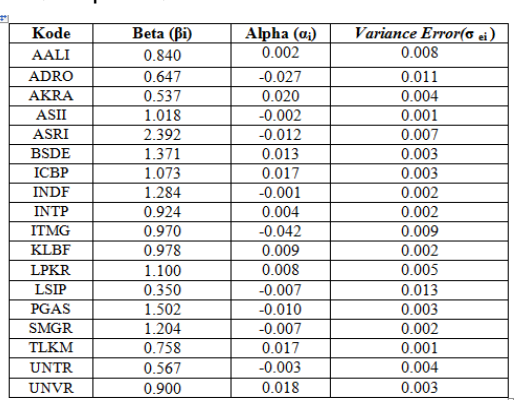

Sumber: diolah oleh penulis

Saham yang memiliki nilai beta paling tinggi dimiliki oleh PGAS yaitu 1,502 sedangkan nilai terendah dimiliki oleh LSIP yaitu 0,350. Semakin besar beta suatu sekuritas, semakin besar pula kepekaan 
return sekuritas terhadap perubahan return pasar. Nilai alpha yang paling tinggi dimiliki oleh AKRA yaitu sebesar 0,020 dan nilai paling rendah dimiliki oleh ITMG dengan nilai -0,042. Sedangkan untuk variance error paling tinggi dimiliki oleh LSIP dengan nilai 0,013 dan nilai yang paling rendah dimiliki oleh ASII dan TLKM dengan nilai sebesar 0,001.

c. Pembentuk Portofolio Optimal

Dikatakan masuk kandidat portofolio optimal apabila nilai ERB $>C^{*}$. C* adalah nilai $\mathrm{Ci}$ yang paling tinggi.

Tabel 5

Perbandingan ERB dengan $\mathrm{Ci}$

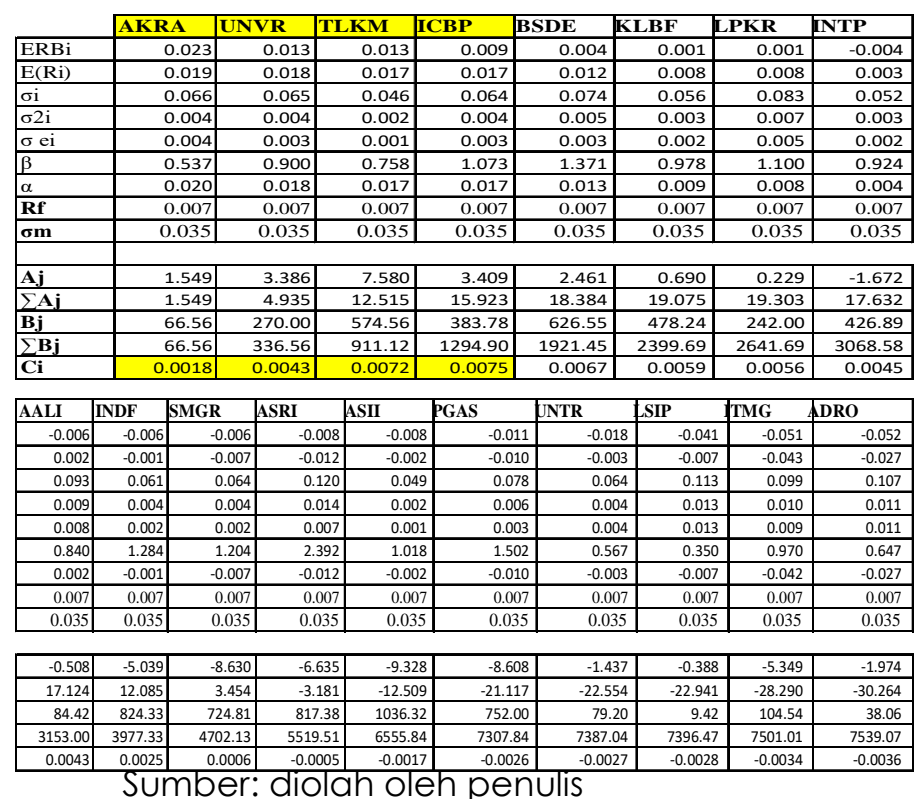

Nilai $C^{*}$ adalah nilai $C i$ yang paling tinggi, berdasarkan tabel 5 nilai $C^{*}$ adalah 0.0075 dengan ERB 0,009 yang dimiliki oleh saham ICBP. Dengan demikian yang memiliki nilai ERB diatas 0,009 adalah saham AKRA dengan nilai ERB 0.023, UNVR dengan nilai ERB 0,013, TLKM dengan nilai ERB 0,013, dan ICBP dengan nilai ERB 0.009 .
Sehingga hanya empat saham tersebut yang memenuhi kriteria pembentuk portofolio optimal yaitu saham AKRA, UNVR, TLKM dan ICBP.

Tabel 6

Return dan risiko Portofolio Optimal Terbentuk

\begin{tabular}{|c|c|c|}
\hline PORTOFOLIO & $\mathrm{E}(\mathrm{Ri})$ & $\sigma \mathrm{i}$ \\
\hline AKRA & 0.019 & 0.066 \\
\hline UNVR & 0.018 & 0.065 \\
\hline TLKM & 0.017 & 0.046 \\
\hline ICBP & 0.017 & 0.064 \\
\hline TOTAL & 0.018 & 0.010 \\
\hline
\end{tabular}

Sumber: diolah oleh penulis

Pada tabel 6 Portofolio tersebut adalah AKRA, UNVR, TLKM, dan ICBP. Rata-ratareturn portofolio yaitu 0,018. Dengan masing-masing saham AKRA memiliki return 0,019, UNVR memiliki return 0,019, TLKM memiliki return 0,017 dan saham ICBP memiliki return 0,017.

Kemudian risiko portofolio yang ditunjukkan dengan standar deviasi memilik rata-rata risiko 0.010 dengan masing-masing saham AKRA memiliki risiko 0.066, UNVR memiliki risiko 0.065, TLKM memiliki risiko 0.046, dan ICBP memiliki risiko 0.064 .

Setelah diketahui niliai saham yang masuk dalam kandidat portofolio optimal, selanjutnya diukur kinerjanya pada tahun 2016

\section{Kinerja Portofolio Optimal}

Tabel 7

Return Portofolio Optimal Saham Jakarta Islamic Index Tahun 2016

\begin{tabular}{|l|c|c|c|c|c|c|}
\hline \multicolumn{1}{|c|}{ PORTOFOLIO } & FEBRUARI & MARET & APRIL & MEI & JUNI & JULI \\
\hline AKRA & 0.082 & -0.048 & -0.094 & -0.089 & 0.000 & 0.090 \\
\hline UNVR & 0.143 & 0.065 & 0.001 & -0.009 & 0.000 & 0.028 \\
\hline TLKM & 0.043 & 0.021 & 0.041 & 0.044 & 0.044 & 0.088 \\
\hline ICBP & 0.076 & 0.016 & -0.031 & 0.050 & 0.063 & -0.063 \\
\hline jumlah & 0.345 & 0.055 & -0.084 & -0.003 & 0.107 & 0.144 \\
\hline E(Rp) & 0.086 & 0.014 & -0.021 & -0.001 & 0.027 & 0.036 \\
\hline rata-rata E(Rp) & \multicolumn{7}{|c|c|c|}{} \\
\hline
\end{tabular}


Sumber: diolah oleh penulis

Berdasarkan tabel 7 tingkat return realisasi portofolio bulan Februari sebesar 0,086, bulan Maret 0,014, bulan April 0,021, bulan Mei $-0,001$, bulan Juni 0,027, dan bulan Juli 0,036, sehingga diperoleh return ekspektasi portofolio sebesar 0,024. Hasil return realisasi diperoleh dari harga penutupan bulan sekarang dikurangi bulan sebelumnya dibagi bulan sebelumnya.

Tabel 8

Standar Deviasi Portofolio Optimal Saham Jakarta Islamic Index Tahun 2016

\begin{tabular}{|c|c|c|c|c|c|c|c|c|c|c|}
\hline \multirow{2}{*}{ PORTOFOLIO } & \multirow{2}{*}{ FEBRUAR } & \multirow{2}{*}{ MARET } & \multirow{2}{*}{ APRIL } & \multirow{2}{*}{$\mathrm{MEI}$} & \multirow{2}{*}{ JUNI } & \multirow{2}{*}{ JULI } & \multirow{2}{*}{ Ri } & \multicolumn{3}{|c|}{ STANDARDEVIASI } \\
\hline & & & & & & & & SDi & RiE:E(Rp) & SDp \\
\hline AKRA & 0.082 & .0 .048 & -0.094 & 0.089 & 6.000 & .090 & -0.009 & 0.082 & 0.033 & \\
\hline UNVR & 0.143 & 0.065 & 0.001 & 0.009 & h.000 & 0.028 & 0.038 & 0.058 & 0.0140 & \\
\hline TLKM & 0.043 & 0.021 & 0.041 & 0.044 & 0.044 & .088 & 0.047 & 0.022 & 0.0230 & \\
\hline ICBP & 0.076 & 0.016 & -0.031 & 0.050 & 0.063. & 0.063 & 0.119 & 0.055 & 0.0054 & \\
\hline & & & & & & & & 0.054 & & \\
\hline
\end{tabular}

Sumber: diolah oleh penulis

Berdasarkan tabel 8 return masingmasing saham AKRA sebesar -0,009, UNVR sebesar 0.038, TLKM sebesar 0,047 dan ICBP sebesar 0,019. Sedangkan standar deviasi (risiko) masing-masing saham sebesar AKRA sebesar 0.082, UNVR sebesar 0,058, TLKM sebesar 0,022, ICBP sebesar 0,055 . Sehingga diperoleh rata-rata standar deviasi (risiko) sebesar 0,054. Sedangkan standar deviasi (risiko) portofolio 0,025. Perhitungan standar deviasi portofolio diperoleh dari akar total return realisasi saham dikurangi return ekspektasi dibagi jumlah observasi atau dengan excel menggunakan rumus Stdev.

Tabel 9

Kinerja Portofolio Optimal Saham Jakarta Islamic Index Tahun 2016

\begin{tabular}{|l|l|}
\hline Return ekspektasi [E(Rp)] & 0.024 \\
\hline Standar deviasi [SDp] & 0.025 \\
\hline Rf [riskfree] & 0.006 \\
\hline Spm [indeks sharpe] & 0.720 \\
\hline
\end{tabular}

Sumber: diolah oleh penulis

Berdasarkan tabel 9 maka diperoleh kinerja portofolio optimal saham yang terdaftar di Jakarta Islamic Index tahun 2016 yang di tunjukkan dengan indeks sharpesebesar 0,720 , dengan return 0,024 dan standar deviasi 0,025 . Hasil diperoleh melalui perhitungan return dikurangi aset bebas risiko (Rf) dibagi standara deviasi.

4. Kinerja Pasar

Tabel 10

Kinerja Pasar Tahun 2016

\begin{tabular}{l|l|}
\hline return ekspektasi [E(Rm)] & 0.031 \\
\hline standar deviasi [SDm] & 0.037 \\
\hline Rf [riskfree] & 0.006 \\
\hline Spm [indeks sharpe] & 0.676 \\
\hline \multicolumn{2}{|l|}{ Sumber: diolah oleh penulis }
\end{tabular}

Berdasarkan tabel 10 maka diperoleh kinerja pasar tahun 2016 yang di tunjukkan dengan indeks sharpe sebesar 0,676 , dengan return 0,031 dan standar deviasi 0,037.

\section{Pembahasan}

Portofolio Optimal Terbentuk Tahun 20132015

Pada penelitian ini portofolio yang terbentuk dihasilkan dari 18 saham yang konsisten pada Jakarta Islamic Index periode Desember 2013-Juli 2016.

Portofolio tersebut adalah AKRA, UNVR, TLKM, dan ICBP. BerikUt adalah perbandingan return portofolio, Pasar, dan SBI:

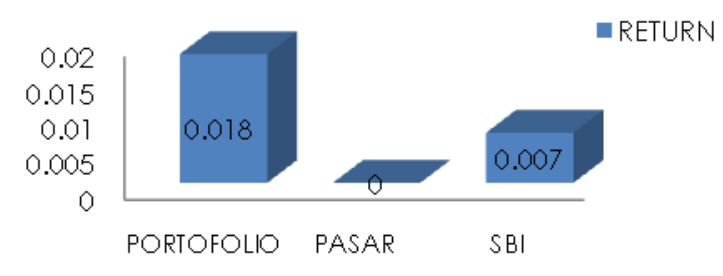


Sumber: diolah oleh penulis

Grafik 2

Perbandingan Return

Empat saham ini wajar masuk dalam portofolio optimal bisa dilihat dari ratarata return portofolio yaitu 0.018 . Rata-rata Return portofolio tersebut lebih tinggi jika dibandingkan dengan return pasar yaitu sebesar 0,000 dan lebih tinggi juga jika dibandingkan dengan return bebas risiko yaitu hanya sebesar 0.007. Sehingga dengan membentuk portofolio memberikan return yang lebih tinggi dari pada tidak membentuk portofolio.

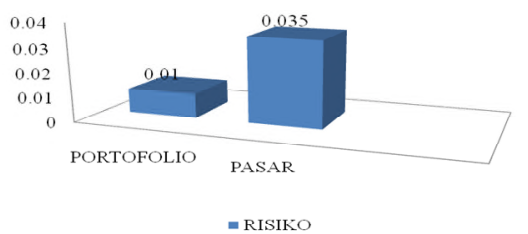

Sumber: diolah oleh penulis

Grafik 3

Perbandingan Risiko

Begitu pula dengan risiko yang ditunjukkan dengan standar deviasi, risiko empat saham pembentuk portofolio memiliki nilai 0,010 lebih rendah dibandingkan dengan risiko pasar yaitu 0,035 . Sehingga dengan membentuk sebuah portofolio mampu memberikan risikoyang lebih rendah dari pada risiko pasar. Penelitian ini sesuai dengan pendapat Tandelilin (2010:156) bahwa risiko dapat dikendalikan, dengan cara memperbanyak jenis saham dalam investasinya.

\section{Kinerja Portofolio Optimal 2016}

Setelah diketahui saham pembentuk portofolio optimal maka selanjutnya diukur kinerja portofolio optimal pada tahun 2016.

Tabel 11

Perbandingan Kinerja Portofolio Optimal dengan Kinerja Pasar Tahun 2016

\begin{tabular}{|l|r|r|}
\hline & PORTOFOLIO & PASAR \\
\hline return ekspektasi [E(R)] & 0.024 & 0.031 \\
\hline standar deviasi [SD] & 0.025 & 0.037 \\
\hline Sp [indeks sharpe] & 0.720 & 0.676 \\
\hline
\end{tabular}

Sumber: diolah oleh penulis

Berdasarkan hasil penelitian dengan menggunakan indeks sharpe maka diketahui indeks sharpe portofolio memiliki nilai 0,720 sedangkan indeks sharpe dari pasar memiliki nilai 0676.

Berdasarkan hasil penelitian membuktikan bahwa return yang tinggi belum tentu memiliki kinerja yang baik. Saham pasar mempunyai return yang lebih tinggi dari pada return portofolio. Risiko yang dihasilkan juga lebih tinggi pasar dari pada risiko portofolio, sehingga kinerja yang dihasilkan lebih tinggi kinerja portofolio dari pada kinerja pasar. Hal ini disebabkan karena risiko yang digambarkan oleh standar deviasi yang dimiliki pasar sangat tinggi yaitu 0,037 yang memiliki selisih dengan return pasar $0,6 \%$, sedangkan return portofolio dengan risiko portofolio hanya selisih $0,1 \%$. Penelitian ini sesuai dengan pendapat Husnan (2003) dalam Herlianto (2013:163164) bahwa tidaklah benar jika portofolio yang memberikan keuntungan yang lebih 
tinggi mesti lebih baik dari pada portofolio lainnya.

Berdasarkan adanya fenomena ini menjelaskan bahwa portofolio yang terbentuk pada tahun 2013-2015 bagus pada tahun 2016. Sehingga investor atau manajer investasi dapat menjadikan portofolio ini sebagai pertimbangan dalam berinvestasi.

\section{SIMPULAN}

Saham-saham pembentuk portofolio optimal berdasarkan saham yang aktif di Jakarta Islamic Index pada periode Januari2013-Juli 2016 adalah PT. Unilever Indonesia TbK (UNVR), Indofood CBP Sukses Makmur Tbk. (ICBP), PT. Telekomunikasi Indonesia Tbk (TLKM), dan AKR Corporindo Tbk. (AKRA). Pembentukan portofolio optimal dengan menggunakan model indeks tunggal.

Kinerja portofolio yang diukur dengan menggunakan indeks sharpe pada periode Januari 2016-Juli 2016 menghasilkan nilai 0,720 , sementara kinerja pasar menghasilkan nilai 0,676, dengan demikian indeks sharpe portofolio lebih tinggi dari pada indeks sharpe pasar.

Berdasarkan hasil penelitian membuktikan bahwa return yang tinggi belum tentu memiliki kinerja yang baik. Saham portofolio yang terbentuk mempunyai return yang rendah dari pada return pasar. Begitu pula risiko yang dihasilkan lebih tinggi pasar dari pada portofolio, Sehingga kinerja yang dihasilkan lebih tinggi portofolio dari pada kinerja pasar. Jadi, dalam penelitian ini portofolio yang terbentuk pada tahun 2013-2015 bagus pada periode 2016 sehingga investor atau manajer investasi dapat menjadikan portofolio ini sebagai pertimbangan dalam berinvestasi.

\section{DAFTAR PUSTAKA}

Alfirdaus, igra'.2011. Jauhi Saham Sebelum Baca Buku Saktilni. Jogjakarta: DIVA Press

Anshori, Muslich dan Sri Isnawi. 2009. Buku Ajar: Metodologi Penelitian Kuantitatif. Surabaya: Airlangga University Press

Dewan Syariah Nasional (DSN) Majelis Ulama Indoensia (MUI), Fatwa Dewan Syariah Nasional Majelis Ulama Indonesia No.05/DSN-MUI/IV/2000 tentang jual beli salam, Jakarta; 2000

Dewan Syariah Nasional (DSN) Majelis Ulama Indoensia (MUI), Fatwa Dewan Syariah Nasional Majelis Ulama Indonesia No. 20/DSN-MUI/IX/2000 tentang Pedoman Pelaksanaan Investasi untuk Reksadana Syariah, Jakarta; 2000

Dewan Syariah Nasional (DSN) Majelis Ulama Indoensia (MUI), Fatwa Dewan Syariah Nasional Majelis Ulama Indonesia fatwa No. 40/DSNMUI/IX/2003 tentang Pasar Modal serta Pedoman Umum Penerapan Prinsip Syariah di Bidang Pasar Modal Jakarta; 2003

Fahmi, Irham. 2006. Analisis Investasi dalam Perspektif Ekonomi dan Politik. Bandung: PT Fefika Aditama

Fitriaty dkk, .2012.Analisis Kinerja Portofolio Optimal pada Saham-Saham Jakarta Islamic Index (JII) Periode 20102012.Mankeu, Vol 3 No.1 hlm. 374-463. Universitas Jambi

Halim, Abdul. 2005. Analisis Investasi. Jakarta: Salemba Empat

Herlianto, didit. 2013. Manajemen Investasi Plus Jurus Mendeteksi Investasi Bodong. Yogyakarta: Gosyen Publishing.

Husnan, Suad. 1994. Dasar-dasar Teori Portofolio dan Analisis Sekuritas. Edisi Kedua. Yogyakarta: UPP AMP YKPN 
Nafik, Muhamad. 2009. Bursa Efek dan Investasi Syariah. Cetakan petama. Jakarta: PT. Serambi Ilmu semesta

Jogiyanto, Hartono. 2010. Teori Portofolio dan Analisis Investasi. Yogyakarta: BPFE

Krugmen, Paul dan Obstfeld Maurice.2000. Ekonomi Internasional dan Teori Kebijakan. Jakarta: Rajawali Press

Prastowo, Andi. 2011. Memahami MetodeMetode Penelitian. Yogyakarta: Az-Ruzz media

Sukarno, M. 2007 Analisis Pembentukan Portofolio Optimal Saham Menggunakan Metode Single Indeks di Bursa Efek Jakarta. Tesis. Tidak Dipublikasikan. Program Pasca Sarjana Universitas Diponegoro, Semarang

Sugiyono. 2010. Metoda Penelitian Pendidikan (Pendekatan Kuantitatif, Kualitatifdan R\&D). Bandung: Alfabeta

Susilo, Bambang D. 2009. Pasar Modal. Cetakan Pertama. Yogyakarta: UPP STIM YKPM

Tandelilin, eduardus. 2010. Portofolio dan Investasi. Yogjakarta: Penerbit Kanisius

Wirartha, I Made.2006. Metodologi Penelitian Sosial Ekonomi. Denpasar: Penerbit Andi

Zubir, Zalmi. 2011. Manajemen Portofolio Penerapannya dalam Investasi Saham. Jakarta: Salemba Empat

2009. Pedoman Penulisan Pembimbingan dan Ujian Skripsi. Surabaya: Airlangga University Press 2016. Bareksa (Online) http://www. bareksa.com/id/text/2016/07/19/kinerja -reksa-dana-saham-tertinggal-ihsg-5tahun-terakhir-apapenyebabnya/13636/news. Diakses 15 Januari 2017.

http://ayatalquran.net. diakses pada 27 September 2016 pukul 10.15

www.bi.go.id. diakses 2 Oktober 2016 pukul 09.15

www.dunia.investasi.com. diakses 2 Oktober 2016 pukul 13.04

www.e-bursa.com. diakses 2 Oktober 2016 pukul 15.09

www.idx.co.id. diakses 2 Oktober pukul 16.20

www.yahoo.finance.com diakses 3

Oktober pukul 08.05 